RESEARCH ARTICLE

\title{
Examining the Relationship between Teachers' Perception and their Receptivity of Curriculum Integration at American Schools in Dubai, UAE
}

Hanadi Ahmad Saleh ${ }^{\mathrm{a}}$, Enas Ghazy Shaker ${ }^{\mathrm{b}}$

${ }^{\mathrm{a}, \mathrm{b}}$ Faculty of Education, The British University in Dubai, Dubai, UAE

*Corresponding Author

\begin{abstract}
Any inquiry into a shift in the teaching practices and/or curriculum reform motion involves a coincident study on teachers' perceptions and their receptivity towards those practices and/or reform. This study assesses the relationship between teachers' perceptions and their receptivity of the curriculum integration approaches at American curriculum schools in Dubai, UAE. It aims to examine whether the perceptions and the receptivity of the teachers towards curriculum integration models are correlated. Fogarty's ten models of curriculum integration inform the theoretical framework. A quantitative, non-experimental survey constitutes the research approach and the lens of the postpositivism forms the research paradigm. A sample of 275 Math, Science and English teachers working at American curriculum schools in Dubai, represents the study participants. The findings show an overall positive teachers' perception towards curriculum integration and finds a positive correlation between teachers' perceptions and their receptivity to curriculum integration. Though teachers consider curriculum integration complicated and require major shift in the teaching practices, and has heavy work load, they show confidence towards curriculum integration. The presence of a positive correlation could suggest offering and incorporating curriculum integration servicing in the servicing of the school staff to increase their awareness and prepare them for curriculum reform towards integration in subjects. These findings could be generalized and could inform the education authorities to look for ways for driving the motion away from the subject-based curriculum through planning and conducting professional development about the different models of integration when in-servicing teachers at their schools.
\end{abstract} Keywords: Curriculum Integration, Teacher Perception, Teacher Receptivity, Dubai Schools

\section{Introduction}

\subsection{Research Background and Problem Statement}

The economic and social development of nations and human beings rely on well-educated citizens in mathematics and science as agreed in education literature worldwide (Banilower et al., 2013; Binkley, 2012). In this regard, the precedence of the education authorities and policymakers pivot on acts to enhance the mathematical and scientific literacy (Almomani, 2016; Alqasemy, 2013; Kang et al., 2018; Sang et al., 2018). Though most states have adopted or adapted the Common Core State Standards (CCSSs) and the Next Generation Science Standards 
(NGSS) as a latest reform movement in education in 2012 and 2014 respectively (National Research Council, 2012), students are not showing measurable gains in English language arts, science and mathematics in the international assessments scores such as Program for International Student Assessment (PISA) and Trends in International Mathematics and Science (TIMSS) (Marlaine et al., 2015; Mullis et al., 2015; Malkawi \& Rababah, 2018). For instance, the US students who aged 15 years showed similar results in Science or Reading on the PISA in the three consecutive rounds 2009, 2012, 2015. However, their math results decreased in 2015 compared to 2012 and 2009. In addition to that, the students studying in US curriculum schools abroad such as in the UAE have got lower scores in PISA and TIMSS than those of their peers in the United States schools (Marlaine et al., 2015). Therefore, the education authorities and policymakers are encouraged to improve and innovate programs to supply students the opportunity for achievement and growth (First-Rate Education System | UAE Vision, 2021).

While the CCSSs encompass writing, literature, reading foundation skills, language, speaking, and listening for English language arts and Mathematics, the NGSS intertwine the disciplinary core ideas along with the science and engineering practices and crosscutting concepts (Achieve, 2013). All of these standards together frame what a student needs to know at each grade level to be college and career ready. However, the standards alone may not be the change in education that is required to raise students' achievement and attainment in international assessments (English \& King, 2015; Isabelle, 2017). Rather, the key might be how students learn the standards through the curriculum. The present curriculum approach is a subject-based curriculum where each subject area is being taught individually. Noteworthy, the academic topics are not separated into discrete activities in the workplace. Rather, the workforce usually combines mathematics and science to meet the requirements of the workplace (Slomp et al., 2012; Welde, 2016). The development of the twenty-first-century skills requires mastering the competencies of each subject along with the synthesis of knowledge into beneficial problem-solving plans (Binkley, 2012).

Put together, instead of using a subject-based curriculum to educate students, a shift in how curricula are organized is highly required. One way to organize these standards is through curriculum integration models which are not new to educational professionals (Drake \&Burns, 2004; Fogarty, 1991). Indeed, curriculum integration approach joins the subjects, the standards and/or the topics they cover (Fogarty, 1991; Drake \& Savage, 2016). It has been greatly recommended and utilized in k-12 classrooms as John Dewey's launched integrated approaches to organizing school teaching (Lewis \& Shaha, 2003). Interestingly, the idea for integrating subjects has been long promoted by the reform movements to enhance the UAE's competitiveness through a specific focus upon curricular improvement of math and science education for all students.

Three main topics have been found to be the pivot of research studies on curriculum integration. Where some studies have investigated the effectiveness of curriculum integration regarding whether the integrated curriculum can improve students' achievement and performance (MacMath et al., 2009; Orillion, 2009), other studies have focused on the significance of teachers' skills for implementing integrated curriculum (Harrell, 2010; Richards and Shea, 2006). Yet, few studies have explored the factors that are critical and could affect curriculum implementation (Meister and Nolan, 2001; Wallace et al., 2007). However, helping students to enhance their 
academic achievement through the adoption and implementation of curriculum integration has necessitated for teachers to have reasonable perceptions and receptivity about this approach. Noticeably, there is a lack of research studies that examine teachers' perception and their receptivity of curriculum integration. Thereby, the current study has been contemplated to fill this gap in literature.

\subsection{Aim and Objectives}

The purpose of this quantitative study is to examine whether teachers' perceptions and their receptivity towards curriculum integration at American curriculum schools in Dubai are correlated. The objectives of the study are to:

- Examine teachers' perceptions toward curriculum integration.

- Evaluate teachers' receptivity of curriculum integration.

- Assess whether teachers' perceptions and their receptivity of curriculum integration correlate.

\subsection{Research Questions}

This research study frames three research questions. Besides, it tests one hypothesis as indicated below.

RQ1 What are the perceptions of teachers towards curriculum integration at American curriculum schools in Dubai?

RQ2 To what extent do teachers feel confident about or affronted by adopting curriculum integration?

RQ3 Is there any statistically significant correlation between teachers' receptivity and their Perceptions of the curriculum integration?

Hyp0 There is no significant correlation between teachers' receptivity and their perceptions of the curriculum integration.

Hyp1 There is a significant correlation between teachers' receptivity and their perceptions of the curriculum integration models.

\subsection{Significance of the Study}

Teachers' perceptions and their receptivity to educational reforms and how these impact the process of decision making and the teaching practices have been underscored. Thereby, any inquiry into a shift in the teaching practices and/or curriculum reform motion have involved a coincident study on teachers' perceptions and their receptivity towards those practices and/or reform. Consequently, reporting the voice of the teachers working in American curriculum schools in Dubai is found to be both significant and relevant to avail the UAE national agenda targets. Theoretically, the findings would contribute to the international debates about the adoption of curriculum integration standards to replace the subject-based approaches. Moreover, the findings would fill the research gap in the UAE context and thereby act as a precursor for future studies. Practically, the findings could provide a roadway for theoretical support in teaching practices while the teachers are implementing curriculum integration. Furthermore, findings on the relationship between teachers' perceptions and their receptivity of curriculum integration might impact teachers' ability what they will bring to the classroom and what they will teach. Besides, the findings could inform the education authorities to look for ways for driving 
the motion away from the subject-based curriculum through planning and conducting professional development sessions.

\section{Literature Review}

\subsection{Fogarty's Models of Curriculum Integration}

The concept of curriculum integration has been framed within Fogarty (1991) models which stand as an extrapolation of Jacobs' (1989) design options for curriculum integration. These models have been based on a continuum from less to more curriculum integration where the integration could be within 'single disciplines', 'across several disciplines' and 'within and across learners themselves' (Figure 1). The designation of the model is essential to reveal the purpose and the direction of implementation of curriculum integration. The ten models proposed by Fogarty have been presented below and they have built up a survey which has been adopted to be the instrument for collecting data in this study.

In his article, Newman (1993) presented all of Fogarty's models of curriculum integration that are adopted in the current study. While the fragmented model presents an isolated and distinct nature of the disciplines, the connected model still has separate disciplines but features the links between concepts within each discipline. The third model in the nested where the social and thinking skills have been integrated within subject content, then the sequenced model has proposed to teach these integrated competencies in a pre-determined order (Newman, 1993). Though the commonalities between subjects have been examined in the shared model, relating these commonalities to a given theme has been introduced in the webbed model. While the threaded model has proposed the embodiment of various skills across the curricula, the integrated model has blended the study skills, concepts and knowledge. Lastly, the immersed model has depended on the active integration of the different disciplined by the learner himself and the networked model has proposed combining a group of learners (Fogarty, 1991).

Figure 1: How to Integrate Curriculum? (Fogarty, 1991)

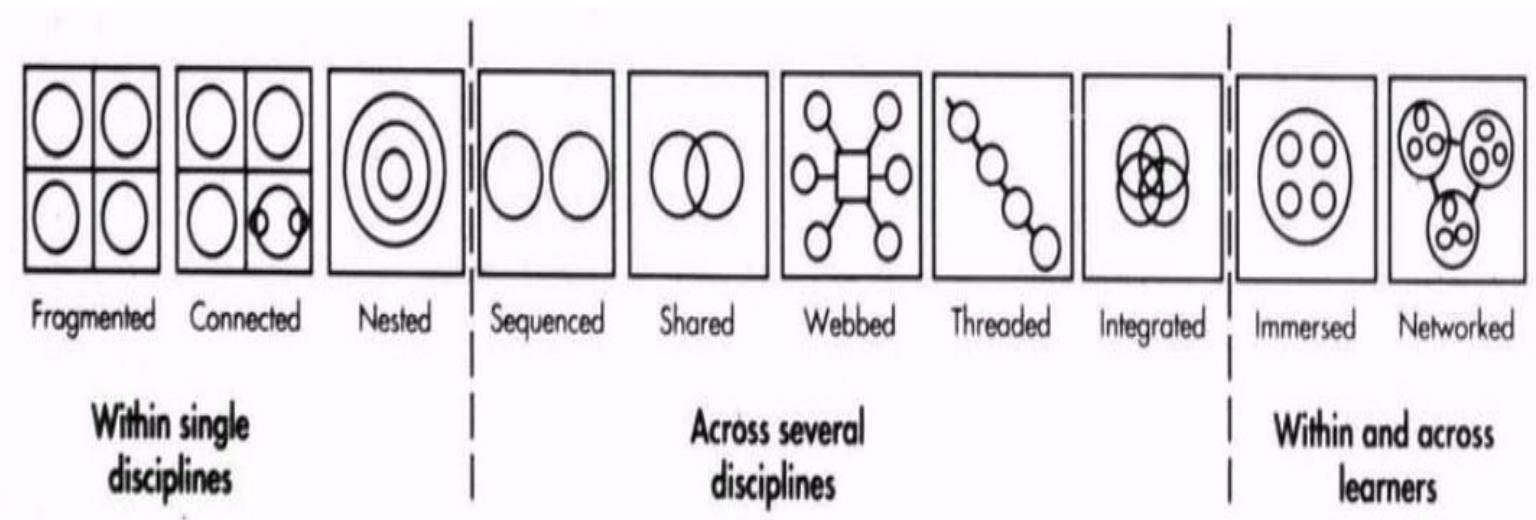

\subsection{Empirical Studies on Curriculum Integration}

Three main topics have been found to be the pivot of research studies on curriculum integration. Research studies have widely investigated the effectiveness of curriculum integration regarding whether this approach can improve students' achievement and performance (Cviko et al., 2013; Zhbanova et al., 2010; Lewis \& Shaha, 2003; MacMath et al., 2009; Orillion, 2009). It has been proven that students in integrated approaches performed better on standardized 
achievement tests than those students from the traditional curriculum approaches. This effectiveness of curriculum integration has been confirmed in many quantitative and qualitative studies who have overwhelmingly underpinned the potential of gaining from curriculum integration in various areas including academic achievement, teamwork, ownership, motivation and attitudes (Cviko et al., 2013; MacMath et al., 2009, Lewis \& Shaha, 2003; Zhbanova et al., 2010). Other studies have explored the ways and approaches for curriculum integration (Drake \& Savage, 2016). In this study, they have emphasized on the curriculum integration which encourages not to separate by subject matter but rather through questions and concept explorations or to have connections through themes, issues or real-world problems. All of the standards where literature and informative texts can link many areas within subjects have been fit under this approach of the curriculum (Drake \&Savage, 2016). The process of designing and implementing curriculum integration has necessitated writing a curriculum that is specific to educational timelines along with the accountabilities of teachers where they must get rid of the boundaries between subjects and replace the old models of teaching (Drake \& Savage, 2016).

Other studies have focused on the factors that might impact the implementation of curriculum integration in the schools such as educators' opinions along with their knowledge and competences in implementing curriculum integration and many other concerns above teaching (Harrell, 2010; Richards \& Shea, 2006; Hinde, 2005). For instance, Hinde (2005) research has reported that curriculum integration implementation is challenged by both teachers' knowledge and skills. According to him, the development of overall teaching competency including content knowledge in different subjects, theoretical knowledge on curriculum integration and pedagogical knowledge are the major challenges that make the usage of curriculum integration complicated. Harrell (2010) research has found that many teachers have possessed inadequate content knowledge required to teach science making them not competent to teach the integrated curriculum. This has been emphasized on a more recent study for Lam et al. (2013) where teachers' insufficient knowledge in various subjects hindered them from determining the main ideas to be taught in an integrated approach.

Yet few studies have investigated the teachers' perceptions in designing and implementing curriculum integration. A study for Lun (2006) has shed light on the beliefs of primary school teachers towards curriculum integration using a survey design. Those teachers have believed that curriculum integration has improved the linkage between the different subject areas and related the classroom learning to real-world experiences. Moreover, the teachers have believed that curriculum integration assisted in improving the academic performance of students and encouraged their meaningful application of knowledge. Another study for Ozturk and Erden (2011) has extended teachers' perceptions on the effectiveness of curriculum integration using a questionnaire for 225 preschool teachers. Those teachers have shown positive perceptions where many teachers have perceived curriculum integration to be efficient in underpinning meaningful learning and adopting an overall development for children.

Though the present educational reforms aim to improve the competitiveness of UAE internationally through specific concentration on moving towards curriculum integration approach to replace subject-based curriculum at American International schools in Dubai (Marlaine et al., 2015; Mullis et al., 2015), there are no studies on examining the relationship 
between teachers' perceptions and their receptivity to educational reforms and how these impact the process of decision making and the teaching practices. Given that any inquiry into a shift in the teaching practices and/or curriculum reform motion has involved a coincident study on teachers' perceptions and their receptivity towards those practices and/or reform, this study has addressed this gap in literature.

\section{Methodology}

\subsection{Research Approach and Design}

The current study has adopted the quantitative research approach using non-experimental survey design along with postpositivism philosophical view in the data analysis (Creswell, 2017). This approach has been depended on inductive reasoning, and it has utilized numbers for measuring variables in social science and thereby ended with objective data. This design was appropriate for this study as surveys are suitable for measuring the perceptions of respondents (Muijs, 2010). Teachers' perceptions and teachers' receptivity toward curriculum integration were the variables of this study. Though the causal effects could be identified through an experimental design, this design has been excluded due to its inconvenience in addressing the research questions. Indeed, the experimental design required control variables which have been found logistically difficult to manipulate (Muijs, 2010). Instead, the non-experimental design has been found to be less invasive with the participants and provides valuable scientific data despite its defect in inferring causality. Though the survey design is sensitive to the ability of respondents to expend time and effort on the study, it is effective in accessing a large number of respondents at the same time (Cohen et al., 2018). Moreover, comparisons for difference and/or checking for correlations could be done for the survey responses among different groups. Noteworthy, the qualitative research approach has been not fostered due to its subjectivity and deductive reasoning where many realities exist (Creswell, 2017).

\subsection{Population and Sampling}

Based on the data available on the Ministry of Education website in the 2018/19 academic year, the total number of science, math and English language teachers working in American curriculum schools has been found to be 790 which constitute the size of the population (Ministry of Education, 2019). In order to be able to generalize the findings, the representative sample size has to be 259 teachers under 1\% margin errors and $99 \%$ confidence level. However, the researcher has invited 370 teachers as he has assumed that the estimated response rate is $70 \%$. Though the random sampling is a method that ascertains all members in the population have equal opportunities of being chosen and it is more accurate and strict than the non-random sampling, the feasibility and practicality of sampling under certain conditions might be threatened (Trochim, 2006). This is why random sampling has not been used. Rather, a non-random convenience sampling method has been followed for its ease to achieve the size of the representative sample.

\subsection{Data Collection Instrument}

The questionnaire has been made up of three sections (Appendix A). The first section contained five questions for the demographic information of the respondents. The second section 
has been adopted from a study for Newman (1993) to examine teachers' perceptions towards the curriculum integration models. It has been constituted from 50 statements related to Fogarty's (1991) ten models of curriculum integration. Each model has been measured via five representative items using a 5 point - Likert scale. Lastly, the third section has made up of ten items to evaluate teachers' receptivity of the curriculum integration approach.

The internal and external validity along with reliability have been checked for the questionnaire (Creswell, 2017). While the face validity has been checked via asking two educational experts in the field of curriculum and suggesting for changes, the content validity has been checked via the conduction of a pilot study with a group of fifteen teachers working in schools at UAE. Moreover, the construct validity has been examined by calculating Pearson correlation which has been found to be between 0.70 and 0.90 indicating the suitability of the survey items. Although the self-report of the participants might impose internal validity, all threats have been found to be reasonable. On the other side, external validity refers to whether the measures gained from the study sample could be generalized to and across the population from which the sample was drawn (Creswell, 2017). However, this external validity might be threatened due to the non-random sampling process. Regarding reliability, it has been gauged by computing Cronbach's alpha coefficient which has been found to be equal to 0.70 or higher indicating an internal satisfactory reliability (Creswell, 2017).

\subsection{Data Collection Procedure}

An invitation for completing the survey has been sent via email and LinkedIn account of the researcher for all potential participants. Besides, informed consent has been shared with the entire study sample. Noticeable, the researcher is a senior leader in one school in Dubai. He has a lot of connections with other schools across the UAE where he has depended on these connections to achieve the representative sample for the target population. The estimated time to complete the survey is between 15 and 20 minutes. The participants have been given a period of one week to complete the survey. Then, a reminder email has been sent to turn in the survey.

\subsection{Data Analysis}

The collected data has been analyzed via SPSS. Firstly, descriptive statistics including means and standard deviation have been computed. This type of statistics is significant as it provides a mathematical summarization of data showing a richer picture to assess the phenomenon of interest (Muijs, 2010). Composite scores have been calculated to reduce the potential of information overload as well as to have a descriptive score for each model rather than for each statement. Secondly, inferential statistics have been performed to assess the correlation between the study variables. This has been achieved by calculating Spearman-rank order correlation which is suitable for testing a hypothesis assessing the relationships.

\subsection{Ethical Consideration}

All ethical guidelines for a research study have been respected (Creswell, 2017). All participants have been informed about the study's purpose and the potential rewards of participation. The researcher has emphasized the confidentiality, privacy and voluntary participation where the participants have the right not to respond to any question and they could 
withdraw at any time without affecting their relationship with the researcher. The data has been kept on a secured computer which was accessible by the researcher only.

\section{Findings and Discussion}

\subsection{Findings}

The participants' demographic information has been outlined in Table 1. The total number of participants has been found to be 275 teachers indicating $74 \%$ as a response rate which was high enough to represent the target population of the study and thereby generalize the findings. The descriptive and inferential statistical analysis executed on the questionnaire results has been presented in this section. However, for better reporting and analyzing the data, proportional staging for scores categories has been identified (Table 2). Three levels have been decided, low, moderate and high, for determining the categories of agreement.

Table 1: Demographic Information for the Participants in the Questionnaire

\begin{tabular}{|l|l|c|c||}
\hline Demographic Information & Items & Frequency & Percentage (\%) \\
\hline \hline \multirow{3}{*}{ Gender } & Female & 179 & 65 \\
\cline { 2 - 4 } & Male & 96 & 35 \\
\hline \hline \multirow{5}{*}{ Subject Taught } & High School & 91 & 33 \\
\cline { 2 - 4 } & Middle School & 102 & 37 \\
\cline { 2 - 4 } & Elementary School & 61 & 22 \\
\cline { 2 - 4 } & Kindergarten & 21 & 8 \\
\hline \hline \multirow{5}{*}{ Years of Teaching Experience } & $4-6$ & 113 & 41 \\
\cline { 2 - 4 } & Science & 96 & 35 \\
\cline { 2 - 4 } & Mathematics & 66 & 24 \\
\cline { 2 - 4 } & English Language Arts & 33 & 31 \\
\cline { 2 - 4 } & New teacher & 110 & 33 \\
\cline { 2 - 4 } & Over 10 & 33 & 12 \\
\hline \hline
\end{tabular}

Table 2: Proportional Staging for Scores Categories

\begin{tabular}{|l|c|c|c|c|}
\hline Scales & $\begin{array}{c}\text { Minimum- } \\
\text { Maximum Score } \\
\text { Range }\end{array}$ & $\begin{array}{c}\text { Low } \\
\text { Range }\end{array}$ & $\begin{array}{c}\text { Moderate } \\
\text { Range }\end{array}$ & $\begin{array}{c}\text { High } \\
\text { Range }\end{array}$ \\
\hline $\begin{array}{l}\text { Overall Teachers' Perception on } \\
\text { Curriculum Integration }\end{array}$ & $50-250$ & $50-116$ & $117-183$ & $184-250$ \\
\hline $\begin{array}{l}\text { Overall Teachers' Receptivity of } \\
\text { Curriculum Integration }\end{array}$ & $10-50$ & $10-23$ & $24-37$ & $38-50$ \\
\hline $\begin{array}{l}\text { Each of the Ten Models of } \\
\text { Curriculum Integration }\end{array}$ & $5-25$ & $5-11$ & $12-18$ & $19-25$ \\
\hline Any Item in the survey & $1-5$ & $\begin{array}{c}1.0- \\
2.30\end{array}$ & $2.31-3.61$ & $3.62-5.0$ \\
\hline
\end{tabular}

To start with the teachers' perceptions towards each of the ten Fogarty's models, the overall teachers' perception towards curriculum integration based on Fogarty's model has been found to 
be positive (Mean=121.08, $\mathrm{SD}=44.34$ ). However, four of the ten models have received negative perceptions: fragmented (Mean=9.64, $\mathrm{SD}=4.49$ ), connected (Mean=9.16, $\mathrm{SD}=4.49$ ), immersed (Mean=9.41, SD=4.50) and networked (Mean=8.55, SD=4.46) models. Regarding the 'Fragmented Model', the mean scores of its representative items range from 1.23 to 2.82. While the item "each academic subject ought to be seen as a pure entity in and of itself" has received the lowest score (Mean=1.23, $\mathrm{SD}=0.83$ ) and the item "teachers should concentrate on a narrow focus within a subject area" has received the highest score (Mean=2.82, $\mathrm{SD}=0.94)$. Noticeably, the mean scores for the other items have been found below the midpoint (3.00) on the five-point scale (Table 3).

\section{Table 3: Teachers' Perceptions towards Fragmented Model of Curriculum Integration}

\begin{tabular}{||l|l|c|c|c||}
\hline$\#$ & Fragmented Model & Mean & SD & Degree \\
\hline $\mathbf{1}$ & $\begin{array}{l}\text { Each academic subject ought to be seen as a pure } \\
\text { entity in and of itself* }\end{array}$ & 1.23 & 0.83 & Low \\
\hline $\mathbf{2}$ & $\begin{array}{l}\text { Each subject area ought to plan and execute its } \\
\text { topics and content in isolation from other subjects* }\end{array}$ & 1.92 & 0.88 & Low \\
\hline $\mathbf{3}$ & $\begin{array}{l}\text { The traditional model of separate subjects ought to } \\
\text { be maintained* }\end{array}$ & 1.52 & 0.87 & Low \\
\hline $\mathbf{4}$ & $\begin{array}{l}\text { Teachers should be concerned only with cognitive } \\
\text { development of the student as it pertains to a subject } \\
\text { area*. }\end{array}$ & 2.15 & 0.97 & Low \\
\hline $\mathbf{5}$ & $\begin{array}{l}\text { Teachers should concentrate on a narrow focus } \\
\text { within a subject area*. }\end{array}$ & 2.82 & 0.94 & Moderate \\
\hline & \begin{tabular}{l} 
Overall Score of Fragmented Model \\
\hline
\end{tabular} & 9.64 & 4.49 & Low \\
\hline
\end{tabular}

* The questionnaire items are adopted from a study by Newman (1993).

Similarly, the representative items of the 'Connected Model' have received mean scores below the midpoint on the scale where the highest score has been reported for the item "the teacher should make connections within a subject area by asking questions that stretch students' ideas" (Mean=2.37; SD=0.98) and the lowest score have been given for the item "the teacher should explicitly make links between subject areas" (Mean=1.32, SD=0.82) (Table 4).

Table 4: Teachers' Perceptions towards Connected Model of Curriculum Integration

\begin{tabular}{||l|l|c|c|c||}
\hline$\#$ & Connected Model & Mean & SD & Degree \\
\hline $\mathbf{6}$ & $\begin{array}{l}\text { Teachers should help students to make links between } \\
\text { topics, concepts and different year's work within a } \\
\text { subject area*. }\end{array}$ & 2.34 & 0.94 & Moderate \\
\hline $\mathbf{7}$ & $\begin{array}{l}\text { The teacher should explicitly make links between } \\
\text { subject areas*. }\end{array}$ & 1.32 & 0.82 & Low \\
\hline $\mathbf{8}$ & $\begin{array}{l}\text { Key concepts within a subject area ought to be } \\
\text { developed over time*. }\end{array}$ & 1.35 & 0.81 & Low \\
\hline $\mathbf{9}$ & $\begin{array}{l}\text { The teacher should make connections within a subject } \\
\text { area by asking questions that stretch students' ideas*. }\end{array}$ & 2.37 & 0.98 & Moderate \\
\hline $\mathbf{1 0}$ & $\begin{array}{l}\text { Transfer of understanding between academic concepts } \\
\text { within a subject area ought to be encouraged*. }\end{array}$ & 1.78 & 0.94 & Low \\
\hline & \begin{tabular}{l} 
Overall Score of Connected Model \\
\hline
\end{tabular}
\end{tabular}


* The questionnaire items are adopted from a study by Newman (1993).

Noticeably, the teachers have disagreed with all the representative statements for the immersed and networked models. For the 'Immersed Model' (Table 5), the item "themes and problems to be studied should emerge from the student" has received the lowest score (Mean=1.45, SD=0.96) whereas the item "the teacher should provide the student with broad and varied content unified with overriding skills, concepts and attitudes" has got the highest score (Mean=2.22, $\mathrm{SD}=0.93$ ).

Table 5: Teachers' Perceptions towards Immersed Model of Curriculum Integration

\begin{tabular}{|c|c|c|c|c|}
\hline \# & Immersed Model & Mean & SD & Degree \\
\hline 41 & $\begin{array}{l}\text { The teacher should provide the student with broad } \\
\text { and varied content unified with overriding skills, } \\
\text { concepts and attitudes*. }\end{array}$ & 2.22 & 0.93 & Low \\
\hline 42 & $\begin{array}{l}\text { Periods ought to be structured to the needs of the } \\
\text { learners, and the needs of the curriculum are planned } \\
\text { around them*. }\end{array}$ & 1.98 & 0.98 & Low \\
\hline 43 & $\begin{array}{l}\text { Themes and problems to be studied should emerge } \\
\text { from the student*. }\end{array}$ & 1.45 & 0.96 & Low \\
\hline 44 & $\begin{array}{l}\text { Learning should be self-initiated and self-directed } \\
\text { with the teacher providing guidance from the side*. }\end{array}$ & 1.98 & 0.84 & Low \\
\hline 45 & $\begin{array}{l}\text { The curriculum ought to be child-centered and } \\
\text { involve minimal intervention from the teacher*. }\end{array}$ & 1.78 & 0.79 & Low \\
\hline & Overall Score of Immersed Model & 9.41 & 4.5 & Low \\
\hline
\end{tabular}

* The questionnaire items are adopted from a study by Newman (1993).

Regarding the 'Networked Model' (Table 6), the item "students should actively create the curriculum out of their day-day today lives" and the item "the onus of integration ought to move to the student rather than to an outside instructional designer or teacher" have received the lowest (Mean=1.45, $\mathrm{SD}=0.91$ ) and highest (Mean=2.20, $\mathrm{SD}=0.96$ ) scores respectively.

Table 6: Teachers' Perceptions towards Networked Model of Curriculum Integration

\begin{tabular}{||l|l|c|c|c||}
\hline$\#$ & Networked Model & Mean & SD & Degree \\
\hline \hline $\mathbf{4 6}$ & $\begin{array}{l}\text { The teacher should facilitate the students' requests } \\
\text { for networking with others from both within and } \\
\text { outside a subject area as the student continually links } \\
\text { new ideas to old*. }\end{array}$ & 1.56 & 0.89 & Low \\
\hline $\mathbf{4 7}$ & $\begin{array}{l}\text { The onus of integration ought to move to the student } \\
\text { rather than to an outside instructional designer or } \\
\text { teacher*. }\end{array}$ & 2.20 & 0.81 & Low \\
\hline $\mathbf{4 8}$ & $\begin{array}{l}\text { Students should actively create the curriculum out of } \\
\text { their day-today lives*. }\end{array}$ & 1.45 & 0.91 & Low \\
\hline $\mathbf{4 9}$ & $\begin{array}{l}\text { Students should be helped to locate mentors to } \\
\text { extend their learning in executing a "pet project"*. }\end{array}$ & 1.78 & 0.88 & Low \\
\hline $\mathbf{5 0}$ & $\begin{array}{l}\text { Students should take a pro-active approach to } \\
\text { integrated learning and the teacher should take a re- } \\
\text { active approach*. }\end{array}$ & 1.56 & 0.97 & Low \\
\hline & \begin{tabular}{l} 
Overall Score of Networked Model \\
\hline
\end{tabular}
\end{tabular}


* The questionnaire items are adopted from a study by Newman (1993).

The models that have received positive perceptions were webbed (Mean=15.24, $\mathrm{SD}=4.33$ ), threaded (Mean=14.57, $\mathrm{SD}=4.42$ ), sequenced (Mean=14.61, $\mathrm{SD}=4.42$ ), integrated (Mean=14.14, $\mathrm{SD}=4.23$ ), nested (Mean=13.08, $\mathrm{SD}=4.39$ ) and shared models (Mean=12.68, $\mathrm{SD}=4.61$ ). All have received moderate agreement from the teachers. The 'Webbed model' (Table 7 ), which have received the highest agreement, its representative items mean scores range from 2.55 to 3.57 with the highest score for the item "the natural scope and sequence within a subject area should be respected during a theme study" (Mean=3.45, SD=0.88) and the lowest mean score for the item "the natural scope and sequence within a subject area should be respected during a theme study" (Mean=2.55, SD=0.84).

Table 7: Teachers' Perceptions towards Webbed Model of Curriculum Integration

\begin{tabular}{|c|c|c|c|c|}
\hline \# & Webbed Model & Mean & SD & Degree \\
\hline 26 & $\begin{array}{l}\text { The natural scope and sequence within a subject area should } \\
\text { be respected during a theme study*. }\end{array}$ & 2.55 & 0.84 & Moderate \\
\hline 27 & $\begin{array}{l}\text { Generic themes such as "patterns" or "cycles" should be } \\
\text { studied in each appropriate subject area*. }\end{array}$ & 2.78 & 0.86 & Moderate \\
\hline 28 & $\begin{array}{l}\text { Thematic study relevant to the students' developmental } \\
\text { needs, to the subject area and to real-life experiences, should } \\
\text { be pursued within each subject area*. }\end{array}$ & 3.57 & 0.79 & Moderate \\
\hline 29 & $\begin{array}{l}\text { Students should learn various subject matter content through } \\
\text { a broad and relevant themes or problem study*. }\end{array}$ & 3.45 & 0.88 & Moderate \\
\hline 30 & $\begin{array}{l}\text { Different subject area teachers should jointly choose a theme } \\
\text { as an overlay to examine the content in their respective } \\
\text { subjects*. }\end{array}$ & 2.89 & 0.96 & Moderate \\
\hline & Overall Score of Webbed Model & 15.24 & 4.33 & Moderate \\
\hline
\end{tabular}

* The questionnaire items are adopted from a study by Newman (1993).

Likewise, the highest mean score has been reported for the item "similar thinking skills ought to be promoted across the curriculum in various subject areas" (Mean=3.45, SD=0.89) in the 'Threaded model' (Table 8) whereas the lowest has been got for the item "similar thinking skills ought to be promoted across the curriculum in various subject areas" (Mean=2.45, $\mathrm{SD}=0.91)$.

\section{Table 8: Teachers' Perceptions towards Threaded Model of Curriculum Integration}

\begin{tabular}{|l|l|c|c|c||}
\hline$\#$ & Threaded Model & Mean & SD & Degree \\
\hline $\mathbf{3 1}$ & $\begin{array}{l}\text { Similar thinking skills ought to be promoted across the } \\
\text { curriculum in various subject areas*. }\end{array}$ & 3.45 & 0.89 & Moderate \\
\hline $\mathbf{3 2}$ & $\begin{array}{l}\text { The teacher should keep his/her subject content intact as well } \\
\text { as include thinking, cooperating and multiple intelligences } \\
\text { into that content*. }\end{array}$ & 3.33 & 0.83 & Moderate \\
\hline $\mathbf{3 3}$ & $\begin{array}{l}\text { Certain social skills ought to be selected and developed in } \\
\text { different subject areas at each grade level*. }\end{array}$ & 2.68 & 0.81 & Moderate \\
\hline $\mathbf{3 4}$ & $\begin{array}{l}\text { Students at a given grade level should study a comprehensive } \\
\text { curriculum that encourages specific social skills, thinking } \\
\text { skills and other relevant learning-process skills*. }\end{array}$ & 2.66 & 0.89 & Moderate \\
\hline
\end{tabular}




\begin{tabular}{|l|l|c|c|c||}
\hline 35 & $\begin{array}{l}\text { Metacognition or debriefing activities need to be } \\
\text { incorporated in lessons and units across the curriculum in } \\
\text { various subject areas*. }\end{array}$ & 2.45 & 0.91 & Moderate \\
\hline & Overall Score of Threaded Model & 14.57 & 4.42 & Moderate \\
\hline
\end{tabular}

* The questionnaire items are adopted from a study of Newman (1993).

For the 'sequenced model' (Table 9), there was only one item that stated "topics ought to be arranged to coincide with one another across the curriculum" has received a mean score below the midpoint (Mean=1.45, $\mathrm{SD}=0.84$ ), however, the highest score (Mean=3.52, $\mathrm{SD}=0.82$ ) has been reported for the item "While content and skills are specific to a subject area, they should be presented within broad, related concepts common to more subjects".

Table 9: Teachers' Perceptions towards Sequenced Model of Curriculum Integration

\begin{tabular}{|l|l|c|c|c||}
\hline$\#$ & Sequenced Model & Mean & SD & Degree \\
\hline $\mathbf{1 6}$ & $\begin{array}{l}\text { While content and skills are specific to a subject area, } \\
\text { they should be presented within broad, related } \\
\text { concepts common to more subjects*. }\end{array}$ & 3.52 & 0.82 & Moderate \\
\hline $\mathbf{1 7}$ & $\begin{array}{l}\text { Teachers should collaborate with each other in order to } \\
\text { teach the same topic at the same time in different } \\
\text { subject areas*. }\end{array}$ & 3.09 & 0.91 & Moderate \\
\hline $\mathbf{1 8}$ & $\begin{array}{l}\text { Topics ought to be arranged to coincide with one } \\
\text { another across the curriculum*. }\end{array}$ & 1.45 & 0.89 & Low \\
\hline $\mathbf{1 9}$ & $\begin{array}{l}\text { Articulation between the teaching of grade level } \\
\text { subjects ought to be encouraged*. }\end{array}$ & 3.35 & 0.87 & Moderate \\
\hline $\mathbf{2 0}$ & $\begin{array}{l}\text { Learning should become more generalized and more } \\
\text { easily transferred when similar topics are taught in } \\
\text { concert*. }\end{array}$ & 3.20 & 0.93 & Moderate \\
\hline \begin{tabular}{l} 
Overall Score of Sequenced Model \\
\hline
\end{tabular}
\end{tabular}

* The questionnaire items are adopted from a study by Newman (1993).

Regarding the 'Integrated Model' (Table 10), the means scores range from 1.55 to 3.78 with the item "teachers in an interdisciplinary team should selectively delete sections of the traditional curriculum and keep only essential content" has got the lowest score (Mean=1.55, $\mathrm{SD}=0.89$ ) and the item "the periodic, thematic study involving various subject areas and the teaching of separate subjects areas ought to be mutually supportive" has got the highest score (Mean=3.78, $\mathrm{SD}=0.87$ ).

Table 10: Teachers' Perceptions towards Integrated Model of Curriculum Integration

\begin{tabular}{||l|l|c|c|c|}
\hline$\#$ & Integrated Model & Mean & SD & Degree \\
\hline \hline $\mathbf{3 6}$ & $\begin{array}{l}\text { Integrated models should be designed with the student as } \\
\text { the focus, not the content as the focal point* }\end{array}$ & 3.67 & 0.85 & Moderate \\
\hline $\mathbf{3 7}$ & $\begin{array}{l}\text { Teachers in an interdisciplinary team should selectively } \\
\text { delete sections of the traditional curriculum and keep } \\
\text { only essential content*. }\end{array}$ & 1.55 & 0.89 & Low \\
\hline $\mathbf{3 8}$ & $\begin{array}{l}\text { A variety of perspectives from different subject areas } \\
\text { should be organized into a thematic unit or course of }\end{array}$ & 2.57 & 0.81 & Moderate \\
\hline
\end{tabular}




\begin{tabular}{||l|l||c|c|c||}
\hline 39 & $\begin{array}{l}\text { study*. } \\
\begin{array}{l}\text { Teachers should form interdisciplinary teams to plan and } \\
\text { teach essential content through new patterns and } \\
\text { designs*. }\end{array}\end{array}$ & 2.57 & 0.81 & Moderate \\
\hline 40 & $\begin{array}{l}\text { The periodic, thematic study involving various subject } \\
\text { areas and the teaching of separate subjects areas ought to } \\
\text { be mutually supportive* }\end{array}$ & 3.78 & 0.87 & High \\
\hline & \begin{tabular}{l} 
Overall Score of Integrated Model \\
\hline
\end{tabular}
\end{tabular}

* The questionnaire items are adopted from a study by Newman (1993).

For the 'Nested model' (Table 11), the mean scores range from 1.98 to 3.45. While the perceptions towards the item "social skills should be included with content skills within a unit of study in a given subject area" has been reported to have the lowest score (Mean=1.89, SD=0.92) and the perceptions towards the item " the teacher should keep his/her subject area pure and intact while extending the lesson into the areas of social and thinking skills" has been reported to have the highest score (Mean=3.45, $\mathrm{SD}=0.84$ ).

Table 11: Teachers' Perceptions towards Nested Model of Curriculum Integration

\begin{tabular}{|l|l|c|c|c||}
\hline$\#$ & Mested Model & SD & Degree \\
\hline \hline $\mathbf{1 1}$ & $\begin{array}{l}\text { Student learning should be enhanced with activities } \\
\text { promoting intellectual, social emotional development } \\
\text { within any given subject*. }\end{array}$ & 2.56 & 0.84 & Moderate \\
\hline $\begin{array}{l}\text { Social skills should be included with content skills within } \\
\text { a unit of study in a given subject area*. }\end{array}$ & 1.89 & 0.92 & Low \\
\hline $\mathbf{1 3}$ & $\begin{array}{l}\text { Teachers should maximize each lesson to develop social, } \\
\text { thinking, and content-specific skills in combination*. }\end{array}$ & 1.98 & 0.91 & Low \\
\hline $\mathbf{1 4}$ & $\begin{array}{l}\text { Teachers should take advantage of natural combinations } \\
\text { of cognitive and affective skill development* }\end{array}$ & 3.20 & 0.88 & Moderate \\
\hline $\begin{array}{l}\text { The teacher should keep his/her subject area pure and } \\
\text { intact while extending the lesson into the areas of social } \\
\text { and thinking skills*. }\end{array}$ & 3.45 & 0.84 & Moderate \\
\hline \begin{tabular}{l} 
Overall Score of Nested Model \\
\hline
\end{tabular}
\end{tabular}

* The questionnaire items are adopted from a study by Newman (1993).

Lastly, the 'Shared model' (Table 12), the mean scores ranges for 1.57 to 3.20 with the highest score has been reported for the item "related subjects should be brought together in a formal unit or course to study a particular theme" (Mean=3.20, $\mathrm{SD}=0.87$ ) whereas the lowest mean has been reported for the item "team teaching involving teachers of related subjects ought to be encouraged in order to develop a common unit of study" (Mean=1.57, SD=0.93).

Table 12: Teachers' Perceptions towards Shared Model of Curriculum Integration

\begin{tabular}{|l|l|c|c|c|}
\hline$\#$ & Shared Model & Mean & SD & Degree \\
\hline $\mathbf{2 1}$ & $\begin{array}{l}\text { Commonalities between complementary subjects should be } \\
\text { found and merged to form a unit of study* }\end{array}$ & 2.45 & 0.88 & Moderate \\
\hline $\mathbf{2 2}$ & $\begin{array}{l}\text { Team teaching involving teachers of related subjects ought } \\
\text { to be encouraged in order to develop a common unit of } \\
\text { study*. }\end{array}$ & 1.57 & 0.93 & Low \\
\hline
\end{tabular}




\begin{tabular}{|c|c|c|c|c|}
\hline 23 & $\begin{array}{l}\text { Teachers should blend ideas from } 2 \text { or more subjects to } \\
\text { create a unique unit of study*. }\end{array}$ & 2.67 & 0.97 & Moderate \\
\hline 24 & $\begin{array}{l}\text { Related subjects should be brought together in a formal unit } \\
\text { or course to study a particular theme*. }\end{array}$ & 3.20 & 0.87 & Moderate \\
\hline 25 & $\begin{array}{l}\text { The concept of efficiency ought to become the organizing } \\
\text { and planning priority between teachers within strands of } \\
\text { related subjects*. }\end{array}$ & 2.79 & 0.96 & Moderate \\
\hline & Overall Score of Shared Model & 12.68 & 4.61 & Moderate \\
\hline
\end{tabular}

* The questionnaire items are adopted from a study by Newman (1993).

Looking at teachers' receptivity of curriculum integration approaches have shown both the extent to which educators think about the curriculum and their reliance in implementing it on their own in addition to the degree to which they look at the curriculum as practical and suitable to the national context (Table 13). The overall score of this receptivity was moderate (Mean=27.57, $\mathrm{SD}=9.03$ ). It was obvious that the teachers have viewed curriculum integration approach as basically different (Mean=3.98, $\mathrm{SD}=0.80$ ) and better than (Mean=3.45, SD=0.81) the subject-based approach and they have reported that curriculum integration requires a major shift in practice (Mean=3.88, $\mathrm{SD}=0.82$ ) and it is highly flexible (Mean=3.56, $\mathrm{SD}=0.93$ ). Despite its flexibility, teachers have viewed curriculum integration as a complicated approach (Mean=2.78; $\mathrm{SD}=0.86$ ) that requires more work (Mean=1.95; $\mathrm{SD}=0.96$ ). Noticeably, teachers have disagreed with the ease of curriculum integration implementation (Mean=1.68; $\mathrm{SD}=0.96$ ) and they did not report high confidence and trust levels (Mean=2.84; $\mathrm{SD}=0.94$ ) in their abilities about implementing such approach at their schools.

Table 13: Teachers' Receptivity of Curriculum Integration Approach

\begin{tabular}{||l|l|c|c|c||}
\hline$\#$ & Mean & SD & Degree \\
\hline $\mathbf{5 1}$ & Flexible & 3.56 & 0.93 & Moderate \\
\hline $\mathbf{5 2}$ & Complicated & 1.78 & 0.86 & Low \\
\hline $\mathbf{5 3}$ & Practical & 1.89 & 0.98 & Low \\
\hline $\mathbf{5 4}$ & Reasonable workload & 2.56 & 0.97 & Moderate \\
\hline $\mathbf{5 5}$ & Less work than subject-based & 1.95 & 0.96 & Low \\
\hline $\mathbf{5 6}$ & Better than subject based & 3.45 & 0.81 & Moderate \\
\hline $\mathbf{5 7}$ & Easy to implement & 1.68 & 0.96 & Low \\
\hline $\mathbf{5 8}$ & Substantially different & 3.98 & 0.80 & High \\
\hline $\mathbf{5 9}$ & Requires major shift in practice & 3.88 & 0.82 & High \\
\hline $\mathbf{6 0}$ & Confidential about implementation & 2.84 & 0.94 & Moderate \\
\hline & Overall Score of Teachers' Receptivity & 27.57 & 9.03 & Moderate \\
\hline
\end{tabular}

Lastly, Spearman rank-order correlation has been used to check for any statistically significant correlation between the variables. There was a strong significant positive correlation between teachers' perceptions towards curriculum integration and their receptivity of these approaches, (Rho=0.652, $\mathrm{p}<0.01, \mathrm{~N}=275$, 2-tailed) with 99\% confidence level (Table 14). Thereby, the null hypothesis has been rejected providing sufficient evidence to conclude that there was a significant monotonic relationship between the two variables. 
Table 14: Correlations between Teachers' Perceptions and Teachers' Receptivity towa Curriculum Integration

\begin{tabular}{|lll|r|r|}
\hline & & Receptivity & Overall \\
\hline Spearman's rho & Receptivity & Correlation Coefficient & 1.000 & $.652^{* *}$ \\
& &. & .000 \\
& Sig. (2-tailed) & 275 & 275 \\
\cline { 2 - 5 } & $\mathrm{N}$ & $.652^{* *}$ & 1.000 \\
& Perceptions & Correlation Coefficient & .000 &. \\
& & Sig. (2-tailed) & 275 & 275 \\
& $\mathrm{~N}$ & & \\
\hline
\end{tabular}

$* *$. Correlation is significant at the 0.01 level (2-tailed).

\subsection{Discussion}

Based on the survey findings for teachers' perceptions towards each of the ten models of curriculum integration, the first research question has been answered. The overall perception towards curriculum integration has been shown to be positive. This has been found to be consistent with the findings for Tudor (2014) study where the perceptions of primary school teachers were positive towards curriculum integration. Taking it further, it is obvious that the disagreement has been reported for the models that are at the lower and upper ends of the curriculum integration continuum (Refer to section 2.1). Thereby, the teachers' did not agree to teach either distinct and isolated disciplines as presented in the fragmented model, or separate disciplines with connections between concepts within each discipline as suggested in the connected model. Similarly, the teachers did not agree to use either the active integration of the different disciplines by the learner himself or combining group of learners as suggested by the immersed and networked models respectively. On the other side, the teachers have agreed to integrate across several disciplines where they have reported to encourage relating the commonalities to a given theme along with embodiment and blending the study skills, concepts and knowledge across the curricula. Consequently, the findings have suggested that teachers were favouring neither the total isolation of disciplines nor the total integration. Similar studies have shown that most teachers use interdisciplinary learning at the level of a curricular domain rather than integrating contents from different curricular domains (Newman, 1993; Tudor, 2014). Furthermore, the competencies have been thought to be the most important and to be developed in the classrooms (Van de Oudeweetering \& Voogt, 2017; Drake \& Reid, 2018). Interestingly, Fu and Sibert (2017) have reported that teachers intend to utilize less integrated models of the curriculum despite the high agreement levels in the effectiveness of curriculum integration.

Scores on teachers' receptivity of curriculum integration have been used to answer the second research question about the extent of feeling confident about or affronted by adopting curriculum integration approach. The teachers' receptivity was moderate showing somehow confidence levels encountered with potential challenges. They have viewed curriculum integration as complicated and require more work along with the difficulty of implementation of curriculum integration which could be highlighted as challenges for adopting this approach. Consequently, the teachers did not reflect high levels of confidence and trust to replace the subject-based approach with curriculum integration at their schools. This has been found to be consistent with the findings for Lun's (2006) research that has identified the heavy workload and the need for more collaboration between teachers of different subject areas were the biggest 
barriers for implementing curriculum integration. Other studies have highlighted the lack of resources, lack of parent support and information on curriculum integration as obstacles for adopting and implementing this approach (Park, 2008). Fu and Sibert (2017) have reported that the frequency of using integrated activities varied depending on the teachers' planning time and their collaboration with their colleagues. A more recent study has emphasized on several barriers, such as pedagogical and structural challenges, issues about learners and about assessments and lack of teacher support, which might encounter the implementation of STEM approach despite the positivity towards it (Margot \& Kettler, 2019). Collaboration with peers, quality curriculum along with effective professional development has been suggested to improve teachers' effort in implementing STEM education (Margot \& Kettler, 2019).

Lastly, the third research question has been answered by assessing the relationship between teachers' perceptions and their receptivity of curriculum integration. The results have reflected a positive correlation and thereby the null hypothesis has been rejected. This has suggested that both variables depended on each other where the way of viewing the curriculum could affect the perceptions of teachers towards that curriculum and vice versa. However, causation has been highlighted as one of the study limitations. Interestingly, the presence of positive correlation could suggest offering and incorporating curriculum integration servicing in the servicing of the school staff to increase their awareness and prepare them for curriculum reform towards integration in subjects. Many studies have stated that positive evaluation of teachers for the worth of the integrated activities on the cognitive and social development of students has been traced back to the teachers' empirical knowledge of the integrated curriculum (Newman, 1993; Tudor, 2014).

\section{Conclusion, Implications and Limitations}

\subsection{Conclusion}

There is a dilemma in curriculum restructuring. Many factors contribute to the lack of curriculum reforming, including insufficient professional development, teachers' role in writing the curriculum and the absence of administrative leadership. All these factors are contradicted with the teachers' loyalty towards their own subject areas and their sincerity to their integration team. This has ended with increasing teachers' uncertainty and decreasing their confidence to shift from a subject-based approach to curriculum integration approach. With respect to the findings on the survey conducted with 275 science, math and English teachers working at American curriculum schools in Dubai, teachers have appeared to value curriculum integration where their overall perceptions have been found to be positive. Though teachers have considered curriculum integration complicated that required a major shift in the teaching practices and has a heavy workload, they have shown moderate receptivity towards curriculum integration. Teachers' perceptions and their receptivity to curriculum integration have found to be positively correlated.

\subsection{Implications and Limitations}

The size of the sample was representative and thereby the findings could be generalized to the study population. These findings could be utilized to plan and conduct awareness about the different models of integration when in-servicing teachers at their schools. Moreover, the findings could be used to inform teacher initiatives for enhancing the efficiency of curriculum integration 
using the representative items for each of the ten models. Moreover, the positive correlation between the study variables has suggested offering and incorporating curriculum integration servicing in the servicing of the school staff to increase their awareness and prepare them for curriculum reform towards integration in subjects. This study has included the voice of science, math and English teachers working in American curriculum schools in Dubai based on convenience sampling method. However, the demographic variations in the sample such as the gender, years of teaching experience, the grade level they taught and the subject they taught have not brought down in the research questions and data analysis. Thereby, the study could be extended to other American schools across UAE. Moreover, it could be extended to examine whether differences exist due to demographic variations. Noticeably, the study has been limited in considering teachers' perceptions only suggesting future studies to examine the perceptions of school principals, students and their parents towards curriculum integration.

In addition, the data has been collected via one instrument only which was the questionnaire. The researcher has assumed that the participants have provided accurate and honest responses. Noteworthy, Correlation has been assessed between the study variables, however, the causation could not be indicated and there was no way to verify it, this has been considered as a weakness in the study. However, this could suggest for future studies to collect more comprehensive data types such as more qualitative data including classroom observations, interviews and lesson plans. This could help to gather more in-depth information on the topic. Furthermore, future studies could be carried on for one cycle only such as teachers of early childhood, primary teachers, middle school teachers or high school teachers.

\section{References}

[1] Achieve. (2013). DCI arrangements of the next generation science standards. Next Generation Science Standards. 1-103. www.nextgenescience.org/ ngss/NGSS.

[2] Almomani, A. (2016). A suggested vision for teaching science in Jordan in light of (NGSS) [Unpublished doctoral dissertation]. Yarmouk University, Jordan.

[3] Alqasemy. (2013, February 10). Reform the science curriculum in UAE. Emaratalyoum Newspaper. http:// www.emaratalyoum.com/local-section/education/2013-02-101.548461

[4] Banilower, E. R., Smith, P. S., Weiss, I. R., Malzahn, K. a., Campbell, K. M., \& Weis, A. M.(2013). Report of the 2012 National Survey of Science and Mathematics Education. Chapel Hill, NC.

[5] Binkley, M., Erstad, O., Herman, J., Raizen, S., Ripley, M., Miller-Ricci, M., \& Rumble, M. (2012). Defining twenty-first century skills. In P. Griffin, B. McGaw, \& E. Care (Eds.), Assessment and Teaching of 21st Century Skills (pp. 17-66). Springer.

[6] Cohen, L., Manion, L. \& Morrison, K. (2018). Research methods in education (7th ed.). Routledge. 
[7] Creswell, J. (2017). Research design: Qualitative, quantitative, and mixed methods approaches. Sage publications.

[8] Cviko, A., McKenny, S., \& Voogt, J. (2013). The teacher as re-designer of technology integrated activities for early literacy curriculum. Journal of Educational Computing Research, 48(4), 447-468.

[9] Drake, S. M., \& Burns, R. C. (2004). Meeting standards through integrated curriculum, Alexandria/Virginia: Association for Supervision and Curriculum Development. URL: http://www. ascd. org/publications/books/103011/chapters/What-Is-Integrated (1.2. 2017).

[10] Drake, S.M., \& Reid, J. L. (2018). Integrated curriculum as an effective way to teacher $21^{\text {st }}$ Century capabilities. Asia Pacific Journal of Educational Research, 1(1), 31-50.

[11] Drake, S. M., \& Savage, M. J. (2016). Negotiating accountability and integrated curriculum from a global perspective. International Journal of Learning, Teaching and Educational Research, 15(6), 127-144.

[12] Ministry of Education. (2019). Education in the UAE. Retrieved from www.moe.gov.ae/English/Pages/UAE/UaeEdu.aspx

[13] English, L., \& King, D. (2015). STEM learning through engineering design: FourthGrade student's investigations in aerospace. International Journal of STEM Education, 2(14), 2-18.

[14] First-Rate Education System | UAE Vision 2021. (2016). Vision2021.ae. Retrieved 26 May 2016, from https://www.vision2021.ae/en/national-priority-areas/first-rateeducation- system.

[15] Fogarty, R. (1991). The mindful school: How to integrate the curricula. Skylight Publishing.

[16] Fu, Y., \& Sibert, S. (2017). Teachers' perspectives: Factors that impact implementation of integrated curriculum in K-3 classrooms. International Journal of Instruction, 10(1), 169-186.

[17] Harrell, P. E. (2010). Teaching an integrated science curriculum: Linking teacher knowledge and teaching assignments. Issues in Teacher Education, Spring, 19(1), 145-165.

[18] Hinde, E. R. (2005). Revisiting curriculum integration: A fresh look at an old idea. Social Studies, 96(3), 105-111.

[19] Isabelle A. D. (2017). STEM is elementary: Challenges faced by elementary teachers in the era of the next generation science standards. The Educational Forum, 81(1), 8391. 
[20] Jacobs, H. H. (Ed.). (1989) Interdisciplinary curriculum: Design and implementation. Association for Supervision and Curriculum Development.

[21] Kang, E., Donovan, C. and McCarthy, M. (2018). Exploring elementary teachers' pedagogical content knowledge and confidence in implementing the NGSS science and engineering practices. Journal of Science Teacher Education, 29(1), 9-29.

[22] Lam, C. C., Alviar-Martin, T., Adler, S. A., \& Sim, J. B. (2013). Curriculum integration in Singapore: Teachers' perspectives and practice. Teaching and Teacher Education, 31, 23-34.

[23] Lewis, V. K., \& Shaha, S. H. (2003). Maximizing learning and attitudinal gains through integrated curricula. Education, 123(3), 537-547.

[24] Lun, W. (2006). Teach integrated curriculum: Teachers' challenges. Pacific-Asian Educational Journal, 18(1), 88-102.

[25] MacMath, S., Roberts, J., Wallace, J., \& Chi, X. (2009). Curriculum integration and atrisk students: A Canadian case study examining student learning and motivation. British Journal of Special Education, 37(2), 87-94.

[26] Malkawi, A. and Rababah, E. (2018). Jordanian twelfth-grade science teachers' selfreported usage of science and engineering practices in the next generation science standards, International Journal of Science Education, 40(9), 961-976.

[27] Margot, L.C., \& Kettler, T. (2019). Teachers' perception of STEM integration and education: a systematic literature review. International journal of STEM Education, 6(1),2.

[28] Marlaine, E. Lockheed, M. E.; Prokic-Breuer, T. \& Shadrova, A. (2015) The experience of middle-income countries participating in PISA 2000-2015. OECD/World Bank.

[29] Meister, D. G., \& Nolan J. (2001). Out on a limb on our own: Uncertainty and doubt in moving from subject-centered to interdisciplinary teaching. Teachers College Record, 103(4), 608-633.

[30] Mullis, I.V.S.; Martin, M.O; Foy, P. \& Hooper, M. (2015). TIMSS 2015 international results in mathematics. Boston College.

[31] Muijs, D. (2010) Doing Quantitative Research in Education with SPSS. Sage.

[32] National Research Council. (2012). A framework for $k$-12 science education: Practices, crosscutting concepts, and core ideas. National Academies Press.

[33] Newman, R. (1993). Development of a curriculum integration perception survey: Two future middle school staffs' readiness for change, Research in Middle Level Education, $16(2), 7-24$. 
[34] Orillion, M. F. (2009). Interdisciplinary curriculum and student outcomes: The case of a general education course at a research university. The Journal of General Education, 58(1), 1-18.

[35] Ozturk, E., \& Erden, F. T. (2011). Turkish preschool teachers' beliefs on integrated curriculum: integration of visual arts with other activities. Early Childhood Development and Care, 181(7), 891-907.

[36] Park, M. (2008). Implementing curriculum integration: The experiences of Korean elementary teachers. Asia Pacific Education Review, 9(3), 308-319.

[37] Richards, J. C., \& Shea, K. T. (2006). Moving from separate subject to interdisciplinary teaching: The complexity of change in a preservice teacher K-1 early field experience. The Qualitative Report, 11(1), 1-19.

[40] Sang, G., Liang, J.C., Chai, C.S., Dong, Y., \& Tsai, C.C. (2018). Teachers' actual and preferred perceptions of twenty-first century learning competencies: a Chinese perspective. Asia Pacific Education Review, 19(3), 307-317.

[41] Slomp, M., Bernes, K., \& Gunn, T. (2012). Integrating career development into school based curriculum: Preliminary results of an innovative teacher training program. In R. Shea \& R. Joy (Eds.), A multi-sectoral approach to career development: A decade of Canadian research (pp. 442-459). Memorial University of Newfoundland.

[42] Tudor, L. S. (2014). Perception of teachers on curriculum integration. Integration patterns practice. Procedia-Social and Behavioral Sciences, 127, 728-732.

[43] Trochim, W.M. (2006). Nonprobability sampling. Research methods knowledge base, $1(1), 1-10$.

[44] Van de Oudeweetering, K., \& Voogt, J. (2018). Teachers' conceptualization and enactment of twenty-first century competences: exploring dimensions for new curricula. The Curriculum Journal, 29(1), 116-133.

[45] Wallace, J., Sheffield, R., Rennie, L., \& Venville, G. (2007). Looking back, looking forward: Re-searching the conditions for curriculum integration in the middle years of schooling. The Australian Educational Researchers, 34(2), 29-49.

[46] Welde, A.M., Bernes, K.B., Gunn, T.M., \& Ross, S.A. (2016). Career education at the elementary school level: Student and intern teacher perspectives. Journal of Career Development, 43(5), 426-446.

[47] Zhbanova, K. S., Rule, A. C., Montgomery, S. E., \& Nielsen, L. E. (2010). Defining the difference: Comparing integrated and traditional single-subject lessons. Early Childhood Education Journal 38, 251-258. 


\section{Appendix}

I have read and understood the information describing the purpose and content of the following questionnaire.

I am aged 20 years or older. I agree to take part in this research under the terms indicated in the informed consent.

Please mark boxes with $\mathrm{X}$ to indicate your responses

\section{Please indicate your agreement to participate here:}

\section{SECTION I: Demographic Information}

This section contains 5 questions about you. Please respond to each by checking your answer or filling in the blank.

\begin{tabular}{|c|c|c|c|c|}
\hline \multicolumn{5}{|c|}{ Demographic Information } \\
\hline $\begin{array}{c}\text { Your gender } \\
\square \text { Male } \\
\square \text { Female }\end{array}$ & $\begin{array}{l}\text { Grade Level Taught } \\
\square \text { High School } \\
\square \text { Middle School } \\
\square \text { Elementary School } \\
\square \text { KG }\end{array}$ & $\begin{array}{l}\text { Subject you taught } \\
\square \text { Science } \\
\square \text { Math } \\
\square \text { English }\end{array}$ & $\begin{array}{l}\text { Your highest level of education } \\
\square \text { Bachelor } \\
\square \text { Masters } \\
\square \mathrm{PhD} / \text { Doctorate }\end{array}$ & \begin{tabular}{|l} 
Your years of teaching \\
experience \\
$\square$ New teacher \\
$\square 1-3$ years \\
$\square 4-6$ years \\
$\square 7-10$ years \\
$\square$ Over 10 years
\end{tabular} \\
\hline
\end{tabular}

\section{SECTION II: Teachers' Understanding on Curriculum Integration Check.}

This section contains 50 statements about the ten models of curriculum integration. Please respond to each by checking your answer based on the 5 point Likert Scale as indicated below.

$\begin{array}{ccccc}1 & 2 & 3 & 4 & 5 \\ \text { Strongly Disagree } & \text { Disagree } & \text { Neutral } & \text { Agree } & \text { Strongly Agree } \\ \text { (SD) } & \text { (D) } & \text { (N) } & \text { (A) } & \text { (SA) }\end{array}$

\begin{tabular}{|l|l|l|l|l|l|l|}
\hline$\#$ & Fragmented Model & SD (1) & D (2) & N (3) & A (4) & SA (5) \\
\hline $\mathbf{1}$ & $\begin{array}{l}\text { Each academic subject ought to be seen as } \\
\text { a pure entity in and of itself. }\end{array}$ & & & & \\
\hline $\mathbf{2}$ & $\begin{array}{l}\text { Each subject area ought to plan and execute } \\
\text { its topics and content in isolation from } \\
\text { other subjects. }\end{array}$ & $\begin{array}{l}\text { (The traditional model of separate subjects } \\
\text { ought to be maintained. }\end{array}$ & & & & \\
\hline $\mathbf{3}$ & $\begin{array}{l}\text { Teachers should be concerned only with } \\
\text { cognitive development of the student as it } \\
\text { pertains to a subject area. }\end{array}$ & $\begin{array}{l}\text { Teachers should concentrate on a narrow } \\
\text { focus within a subject area. }\end{array}$ & & & & \\
\hline $\mathbf{5}$ & & & & \\
\hline
\end{tabular}

\begin{tabular}{|l|l|l|l|l|l|l|}
\hline & Connected Model & SD (1) & D (2) & N (3) & A (4) & SA (5) \\
\hline $\mathbf{6}$ & $\begin{array}{l}\text { Teachers should help students to make } \\
\text { links between topics, concepts and different } \\
\text { year's work within a subject area. }\end{array}$ & & & & \\
\hline $\mathbf{7}$ & $\begin{array}{l}\text { The teacher should explicitly make links } \\
\text { between subject areas. }\end{array}$ & & & & & \\
\hline $\mathbf{8}$ & $\begin{array}{l}\text { Key concepts within a subject area ought to } \\
\text { be developed over time. }\end{array}$ & & & & & \\
\hline
\end{tabular}




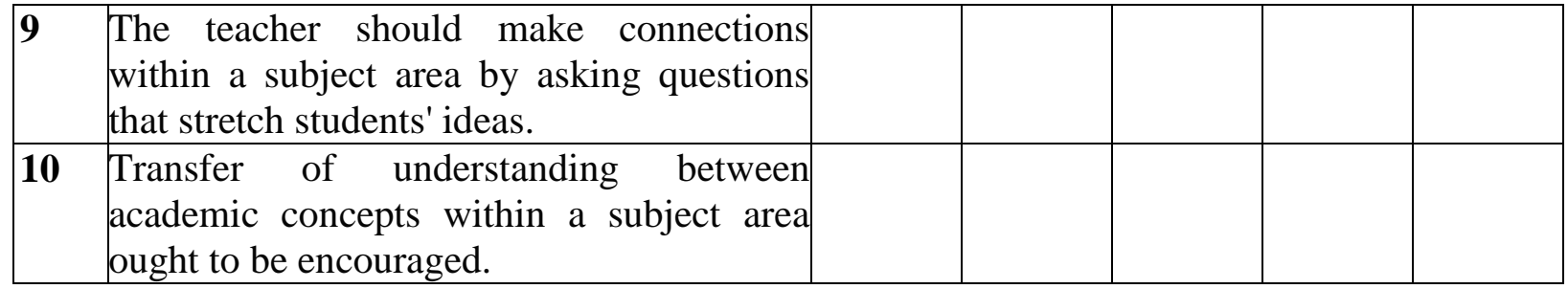

\begin{tabular}{|c|c|c|c|c|c|c|}
\hline & Nested Model & SD (1) & D (2) & $\mathbf{N}(3)$ & A (4) & SA (5) \\
\hline 11 & $\begin{array}{l}\text { Student learning should be enhanced with } \\
\text { activities promoting intellectual, social and } \\
\text { emotional development within any given } \\
\text { subject. }\end{array}$ & & & & & \\
\hline 12 & $\begin{array}{l}\text { Social skills should be included with } \\
\text { content skills within a unit of study in a } \\
\text { given subject area. }\end{array}$ & & & & & \\
\hline 13 & $\begin{array}{l}\text { Teachers should maximize each lesson to } \\
\text { develop social, thinking, and content- } \\
\text { specific skills in combination. }\end{array}$ & & & & & \\
\hline 14 & $\begin{array}{l}\text { Teachers should take advantage of natural } \\
\text { combinations of cognitive and affective } \\
\text { skill development. }\end{array}$ & & & & & \\
\hline 15 & $\begin{array}{l}\text { The teacher should keep his/her subject } \\
\text { area pure and intact while extending the } \\
\text { lesson into the areas of social and thinking } \\
\text { skills. }\end{array}$ & & & & & \\
\hline
\end{tabular}

\begin{tabular}{|l|l|l|l|l|l|}
\hline Sequenced Model & SD (1) & D (2) & N (3) & A (4) & SA (5) \\
\hline $\mathbf{1 6}$ & $\begin{array}{l}\text { While content and skills are specific to a } \\
\text { subject area, they should be presented } \\
\text { within broad, related concepts common to } \\
\text { 2 or more subjects. }\end{array}$ & & & & \\
\hline $\mathbf{1 7}$ & $\begin{array}{l}\text { Teachers should collaborate with each } \\
\text { other in order to teach the same topic at the } \\
\text { same time in different subject areas }\end{array}$ & $\begin{array}{l}\text { Topics ought to be arranged to coincide } \\
\text { with one another across the curriculum. }\end{array}$ & $\begin{array}{l}\text { Articulation between the teaching of grade } \\
\text { level subjects ought to be encouraged }\end{array}$ & & \\
\hline $\mathbf{1 8}$ & $\begin{array}{l}\text { Learning should become more generalized } \\
\text { and more easily transferred when similar } \\
\text { topics are taught in concert. }\end{array}$ & & & \\
\hline
\end{tabular}

\begin{tabular}{|l|l|l|l|l|l|l|}
\hline Shared Model & SD (1) & D (2) & N (3) & A (4) & SA (5) \\
\hline 21 & $\begin{array}{l}\text { Commonalities between complementary } \\
\text { subjects should be found and merged to } \\
\text { form a unit of study. }\end{array}$ & $\begin{array}{l}\text { Team teaching involving teachers of related } \\
\text { subjects ought to be encouraged in order to }\end{array}$ & & & & \\
\hline 22 & \begin{tabular}{l} 
Team \\
\hline
\end{tabular}
\end{tabular}




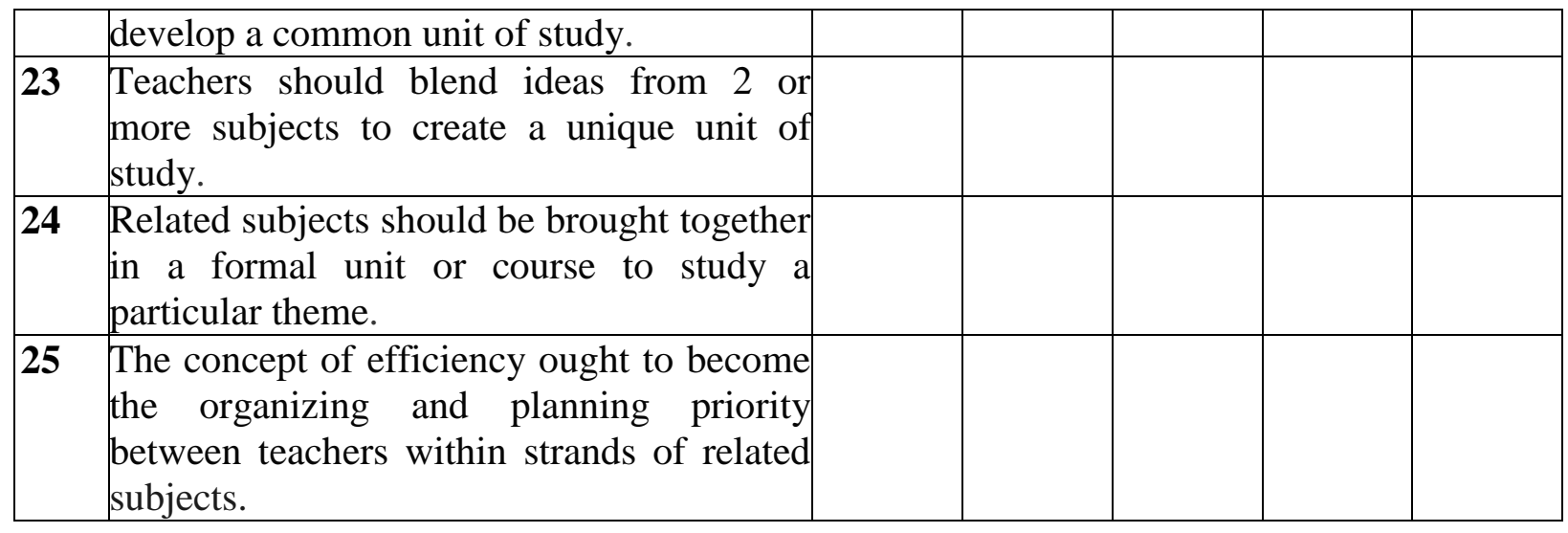

\begin{tabular}{|c|c|c|c|c|c|c|}
\hline & Webbed Model & SD (1) & D (2) & $\mathbf{N}(3)$ & A (4) & SA (5) \\
\hline 26 & $\begin{array}{l}\text { The natural scope and sequence within a } \\
\text { subject area should be respected during a } \\
\text { theme study. }\end{array}$ & & & & & \\
\hline 27 & $\begin{array}{l}\text { Generic themes such as "patterns" or } \\
\text { "cycles" should be studied in each } \\
\text { appropriate subject area. }\end{array}$ & & & & & \\
\hline 28 & $\begin{array}{l}\text { Thematic study relevant to the students' } \\
\text { developmental needs, to the subject area } \\
\text { and to real-life experiences, should be } \\
\text { pursued within each subject area. }\end{array}$ & & & & & \\
\hline 29 & $\begin{array}{l}\text { Students should learn various subject } \\
\text { matter content through a broad and relevant } \\
\text { themes or problem study }\end{array}$ & & & & & \\
\hline 30 & $\begin{array}{l}\text { Different subject area teachers should } \\
\text { jointly choose a theme as an overlay to } \\
\text { examine the content in their respective } \\
\text { subjects. }\end{array}$ & & & & & \\
\hline
\end{tabular}

\begin{tabular}{|c|c|c|c|c|c|c|}
\hline & Threaded Model & SD (1) & D (2) & $\mathbf{N}(3)$ & A (4) & SA (5) \\
\hline 31 & $\begin{array}{l}\text { Similar thinking skills ought to be } \\
\text { promoted across the curriculum in various } \\
\text { subject areas. }\end{array}$ & & & & & \\
\hline 32 & $\begin{array}{l}\text { The teacher should keep his/her subject } \\
\text { content intact as well as include thinking, } \\
\text { cooperating and multiple intelligences into } \\
\text { that content. }\end{array}$ & & & & & \\
\hline 33 & $\begin{array}{l}\text { Certain social skills ought to be selected } \\
\text { and developed in different subject areas at } \\
\text { each grade level. }\end{array}$ & & & & & \\
\hline 34 & $\begin{array}{l}\text { Students at a given grade level should study } \\
\text { a comprehensive curriculum that } \\
\text { encourages specific social skills, thinking } \\
\text { skills and other relevant learning-process } \\
\text { skills. }\end{array}$ & & & & & \\
\hline 35 & $\begin{array}{l}\text { Metacognition activities } \\
\text { incorporated in lessons } \\
\text { various subject areas. }\end{array}$ & & & & & \\
\hline
\end{tabular}




\begin{tabular}{|c|c|c|c|c|c|c|}
\hline & Integrated Model & SD (1) & D (2) & $\mathbf{N}(3)$ & A (4) & SA (5) \\
\hline 36 & $\begin{array}{l}\text { Integrated models should be designed with } \\
\text { the student as the focus, not the content as } \\
\text { the focal point. }\end{array}$ & & & & & \\
\hline 37 & $\begin{array}{l}\text { Teachers in an interdisciplinary team } \\
\text { should selectively delete sections of the } \\
\text { traditional curriculum and keep only } \\
\text { essential content. }\end{array}$ & & & & & \\
\hline 38 & $\begin{array}{l}\text { A variety of perspectives from different } \\
\text { subject areas should be organized into a } \\
\text { thematic unit or course of study. }\end{array}$ & & & & & \\
\hline 39 & $\begin{array}{l}\text { Teachers should form interdisciplinary } \\
\text { teams to plan and teach essential content } \\
\text { through new patterns and designs. }\end{array}$ & & & & & \\
\hline 40 & $\begin{array}{l}\text { The periodic, thematic study involving } \\
\text { various subject areas and the teaching of } \\
\text { separate subjects areas ought to be mutually } \\
\text { supportive. }\end{array}$ & & & & & \\
\hline
\end{tabular}

\begin{tabular}{|l|l|l|l|l|l|l|}
\hline $\mathbf{4 1}$ & Immersed Model & $\begin{array}{l}\text { The teacher should provide the student } \\
\text { with broad and varied content unified with } \\
\text { overriding skills, concepts and attitudes }\end{array}$ & D (2) & N (3) & A (4) & SA (5) \\
\hline $\mathbf{4 2}$ & $\begin{array}{l}\text { Periods ought to be structured to the needs } \\
\text { of the learners and the needs of the } \\
\text { curriculum are planned around them. }\end{array}$ & & & & \\
\hline $\mathbf{4 3}$ & $\begin{array}{l}\text { Themes and problems to be studied should } \\
\text { emerge from the student. }\end{array}$ & & & & \\
\hline $\mathbf{4 4}$ & $\begin{array}{l}\text { Learning should be self-initiated and self- } \\
\text { directed with the teacher providing } \\
\text { guidance from the side. }\end{array}$ & $\begin{array}{l}\text { The curriculum ought to be child-centered } \\
\text { and involve minimal intervention from the } \\
\text { teacher. }\end{array}$ & & & & \\
\hline $\mathbf{4 5}$ & & & & \\
\hline
\end{tabular}

\begin{tabular}{|c|c|c|c|c|c|c|}
\hline & Networked & SD (1) & $\mathbf{D}(2)$ & $\mathbf{N}(3)$ & A (4) & SA (5) \\
\hline 46 & $\begin{array}{l}\text { The teacher should facilitate the students' } \\
\text { requests for networking with others from } \\
\text { both within and outside a subject area as } \\
\text { the student continually links new ideas to } \\
\text { old. }\end{array}$ & & & & & \\
\hline 47 & $\begin{array}{l}\text { The onus of integration ought to move to } \\
\text { the student rather than to an outside } \\
\text { instructional designer or teacher. }\end{array}$ & & & & & \\
\hline 48 & $\begin{array}{l}\text { Students should actively create the } \\
\text { curriculum out of their day-today lives. }\end{array}$ & & & & & \\
\hline 49 & $\begin{array}{l}\text { Students should be helped to locate } \\
\text { mentors to extend their learning in } \\
\text { executing a "pet project". }\end{array}$ & & & & & \\
\hline 50 & Students should take a pro-active approach & & & & & \\
\hline
\end{tabular}


to integrated learning and the teacher should take a re-active approach.

Section III: Teachers' Receptivity of Curriculum Integration

\begin{tabular}{|l|l|l|l|l|l|l|}
\hline & Curriculum Integration is & SD (1) & D (2) & N (3) & A (4) & SA (5) \\
\hline $\mathbf{5 1}$ & Flexible & & & & & \\
\hline $\mathbf{5 2}$ & Complicated & & & & & \\
\hline $\mathbf{5 3}$ & Practical & & & & & \\
\hline $\mathbf{5 4}$ & Reasonable workload & & & & & \\
\hline $\mathbf{5 5}$ & Less work than subject-based & & & & & \\
\hline $\mathbf{5 6}$ & Better than subject based & & & & & \\
\hline $\mathbf{5 7}$ & Easy to implement & & & & & \\
\hline $\mathbf{5 8}$ & Substantially different & & & & & \\
\hline $\mathbf{5 9}$ & Requires major shift in practice & & & & & \\
\hline $\mathbf{6 0}$ & Confidential about implementation & & & & \\
\hline
\end{tabular}

